\title{
EVALUATION OF POTENTIAL USE OF DOMESTIC TREATED EFFLUENTS FOR IRRIGATION IN AREAS SUBJECT TO CONFLICTS OVER WATER USE IN PARACATU RIVER BASIN
}

\author{
Marília Carvalho de Melo \\ Instituto Mineiro de Gestão das Águas e Universidade Vale do Rio Verde, Belo Horizonte, MG, Brasil \\ mariliacmelo@yahoo.com.br
}

\author{
Ana Sílvia Pereira Santos \\ Universidade do Estado do Rio de Janeiro, Rio de Janeiro, RJ, Brasil \\ ana.pereira@uerj.br \\ Nádia Antônia Pinheiro Santos \\ Instituto Mineiro de Gestão das Águas, Belo Horizonte, MG, Brasil \\ nadia.santos@meioambiente.mg.gov.br \\ Bruna Magalhães de Araújo \\ Universidade do Estado do Rio de Janeiro, Rio de Janeiro, RJ, Brasil \\ brunamagalhaes5@gmail.com \\ Josiane Rosa Silva de Oliveira \\ Universidade Federal de Viçosa, Florestal, MG, Brasil \\ josianerso@gmail.com
}

Alessandro Ribeiro Campos

Fundação Estadual do Meio Ambiente, Belo Horizonte, MG, Brasil alessandro.campos@meioambiente.mg.gov.br

\begin{abstract}
The water crisis experienced in recent years in the State of Minas Gerais, Brazil, has corroborated the need of conscientious use of water, based on use-efficient technologies, capable of inducing reuse. Considering worldwide experiences, this study had the objective of analyzing the potential use of domestic sewage treated in irrigated agriculture in the Paracatu river basin, a region recognized as a water conflict area by the State Government. The methodology consisted of evaluating current uses and comparing the volume of raw water demand for irrigation to the volume generated in the sewage treatment plants in the Paracatu river basin; estimating the cost of effluent trucking down to the treatment plants; and comparing the established values paid for the use of raw water and the estimated cost of treated effluent transportation. Water demand for irrigation is approximately $182 \times 10^{6} \mathrm{~m}^{3} /$ year and the volume produced by the sewage treatment plants is $8,36 \times 10^{6} \mathrm{~m}^{3} /$ year, approximately $4,6 \%$ of the irrigation demand. The comparison between the established values paid for the use of raw water and the estimated cost of treated effluent transportation indicates a relationship between 12 e $2 \%$.
\end{abstract}

Keywords: Reuse. Sewage treatment plants. Irrigated agriculture.

\section{AVALIAÇÃO DO POTENCIAL DE USO DE EFLUENTES DOMÉSTICOS TRATADOS PARA IRRIGAÇÃO EM ÁREAS DE CONFLITO PELO USO DA ÁGUA NA BACIA HIDROGRÁFICA DO RIO PARACATU}

\begin{abstract}
RESUMO
Em Minas Gerais, a crise hídrica dos últimos anos corroborou a necessidade de adoção de tecnologias eficientes para a diminuição dos desperdícios e o reuso de água. Vistas as experiências de reuso em vários países, o objetivo deste estudo é analisar o uso potencial de esgoto doméstico tratado na agricultura irrigada na bacia hidrográfica do rio Paracatu, região com Declarações de Área de Conflito - DAC formalizadas. A metodologia consistiu em: avaliar os usos e comparar o volume de água bruta demandado para irrigação com o volume gerado no tratamento de efluentes na bacia do rio Paracatu; estimar o custo do transporte do efluente para reuso, por caminhão pipa; e comparar o valor de cobrança pelo uso dos recursos hídricos com o custo estimado do transporte de água de reuso. A demanda de água bruta para a irrigação é de aproximadamente $182 \times 10^{6} \mathrm{~m}^{3} / \mathrm{ano}$ e o volume de água de esgotos tratados é de $8,36 \times 10^{6} \mathrm{~m}^{3} / \mathrm{ano}$, cerca de $4,6 \%$ da demanda para fins de irrigação. A comparação entre o valor de cobrança da água bruta outorgada e o custo estimado do transporte de água, aponta para uma relação entre 12 e $2 \%$.
\end{abstract}

Palavras-chave: Reuso. Estação de tratamento de esgoto. Agricultura irrigada.

\begin{tabular}{lllll}
\hline Caminhos de Geografia & Uberlândia-MG & v. 21, n. 75 & Jun/2020 & p. $52-63$
\end{tabular}


Evaluation of potential use of domestic treated effluents for irrigation in areas subject to conflicts over water use in Paracatu river basin
Marília Carvalho de Melo

Ana Sílvia Pereira Santos Nádia Antônia Pinheiro Santos Bruna Magalhães de Araújo Josiane Rosa Silva de Oliveira Alessandro Ribeiro Campos

\section{INTRODUCTION}

The many uses of water along with occasional periods of scarcity, distribution anomalies, increased demands and the very environmental degradation lead to a series of tensions and disputes delineate conflicts in strategic watersheds in Brazil (CAVALCANTI and MARQUES, 2016). This is the case of the main basins in the southeastern Brazilian states, which house the highest socio-economic development in the nation.

According to Santos (2016), since the end of 2013, the state of São Paulo has struggled to make water supply available in the Expanded Metropolitan Complex in São Paulo (Macrometropolis) bringing about tension between the states of São Paulo and Rio de Janeiro. This was due to the shortfall of rain in the region or scanty management of the resources, which led the government of São Paulo to announce, in March 2014, their intention of carry out a (new) transposition in the Paraíba do Sul river. However, the Metropolitan Region of Rio de Janeiro depends heavily on the waters of the Paraiba do Sul river. Therefore, the river has become an issue of dispute between the two Brazilian states. Various other circumstances of conflict often flare up in the country due to lack of water in the river basins.

According to Fischer et al. (2016), the current water crisis debate outweighs the actual water scarcity, as it also involves ethical and cultural issues, not to mention environmental issues related to poor public management of this resource, within an economic model that pursues immediate results.

Thus, the search for efficient technological alternatives capable of reducing pressure on surface and groundwater sources that prioritize waste reduction and encourage reuse of water has become crucial (TUNDISI, 2008). There are authors who defend that governance and efficient management are key factors involved in the water scarcity (CASTRO, 2007; SIEGEL, 2017; SOUZA, 2017).

For example, in Israel, according to Siegel (2017), water belongs to the nation and it is up to the government to decide how best to use it for the common good. In this country, the priority of centralized planning is an essential part of the water philosophy, in this case, public agencies govern the water cycle completely, from the first drop to its final use.

Souza (2017) additionally considers the importance of social participation, as an essential human right, for the success of actions of water management and sanitation, mainly in times of water scarcity.

According to the Irrigation Atlas, published by the National Water Agency (ANA - Brazil), irrigated agriculture is the highest water consuming sector in Brazil and in the world: approximately 67 and $70 \%$, respectively. In Brazil, irrigation has an increase projection of up to $42 \%$, with an estimated expansion potential of 11.2 Mha by 2030 (ANA, 2017b).

Agricultural reuse of effluents in the last several decades is a common practice in countries such as Egypt, Australia, Saudi Arabia, Tunisia, Chile and Israel (HESPANHOL, 2002). In 2007, Israel reused $75 \%$ of the effluents generated, against 14\% in Spain, $9 \%$ in Australia, $8 \%$ in Italy and 5\% in Greece (JUANICÓ, 2007). Presently, Israel uses $87 \%$ of treated sewage in irrigation, which is equivalent to more than $40 \%$ of the country's water demand for agriculture (MARIN et at., 2017). Pursuant to studies carried out by Silva et al. (2016), Namibia has been engaged in reuse for irrigation since 1968, and other countries as well not cited above have also been implementing and increasing irrigation system with reuse water, such as Argentina, Cyprus and France.

Considering that it is the largest water consuming sector in the world, whose quality requirements are largely the easiest to achieve in several types of wastewater reuse, it comprehends the highest possibility of reuse of treated domestic sewage - TDS, in terms of volume (ANGELAKIS, 1999). Reuse in these areas provides a reduction of pressure on surface and groundwater sources, maintaining drinking water available for human and livestock consumption (ORON, 1995; HESPANHOL, 2002; LUBELLO, 2004). Additionally, reuse in agriculture contributes to reducing release of effluents into bodies of water and can also provide important source of nutrients, promoting partial replacement and hence the economy of mineral fertilizers (NICHELE, 2009).

In Brazil, it is not yet possible to determine the percentage of water reuse in the national water system. Punctual measures are being implemented, mainly in urban reuse street cleaning, irrigation of urban green areas and clearing of culverts. Furthermore, it is important to emphasize the relevance of industrial reuse, in a decentralized manner, with its own resources and specific objective for this purpose. In the case of irrigation, reuse is being increasingly debated in Brazil, although still only timidly practiced, in general, lacking legal foundations, in areas of extreme water scarcity and, in some cases, with no planning. In their studies, 
Evaluation of potential use of domestic treated effluents for irrigation in areas subject to conflicts over water use in Paracatu river basin
Marília Carvalho de Melo

Ana Sílvia Pereira Santos Nádia Antônia Pinheiro Santos Bruna Magalhães de Araújo Josiane Rosa Silva de Oliveira Alessandro Ribeiro Campos

Araújo et al. (2018b) and Santos et al. (2018) assessed the installed capacities of reuse of effluents in Sewage Treatment Plants (STPs) in the Paraíba do Sul water basin and in the state of Rio de Janeiro. The National Water Agency (ANA) has also been studying the inclusion of water reuse for irrigation as a measure of adaptation to climate change in watersheds of extreme water shortage as it is the case of the PiancóPiranhas-Açú water basin in the states of Rio Grande do Norte and Paraíba. This study was published in 2018 by ANA and is called "Análise custo-benefício de medidas de adaptação à mudança do clima: trajetórias da aplicação na bacia hidrográfica dos rios Piancó-Piranhas-Açü" (Cost benefits analysis of methods of adaptation to climate change: trajectories of application in the Piancó-Piranhas-Açú rivers basin).

Thus, the objective of this present study is to evaluate the potentiality of domestic treated effluents use for irrigation, so that conflicts over water usage in the Paracatu river basin are minimized. This is a region of intense water usage, mainly by the agricultural sector and that has declared four areas of conflict over water usage due to the relation demand-availability.

\section{METHODOLOGY}

\section{DESCRIPTION OF THE STUDY AREA}

The Paracatu river basin is in the northwestern region of the state of Minas Gerais, between the geographic coordinates $15^{\circ} 30^{\prime} / 19^{\circ} 30^{\prime} \mathrm{S}$ e $45^{\circ} 10^{\prime} / 47^{\circ} 30^{\prime} \mathrm{W}$ and covers an area of approximately $45,6000 \mathrm{sq}$. km. $92 \%$ of this area is located in the state of Minas Gerais, $5 \%$ in Goiás and only 3\% in the Federal District, as shown in Figure 1. The Paracatu river, whose source is in the municipality of Lagamar, in Minas Gerais, and flows into the São Francisco river, in the municipality of Buritizeiro, in the Northwest of Minas Gerais. It is $485 \mathrm{~km}$ long and is considered the main watercourse in the basin and one of the main tributaries on the left bank of São Francisco river (IGAM, 2006).

Figure 1 - Location of the Paracatu river water basin, in Minas Gerais.

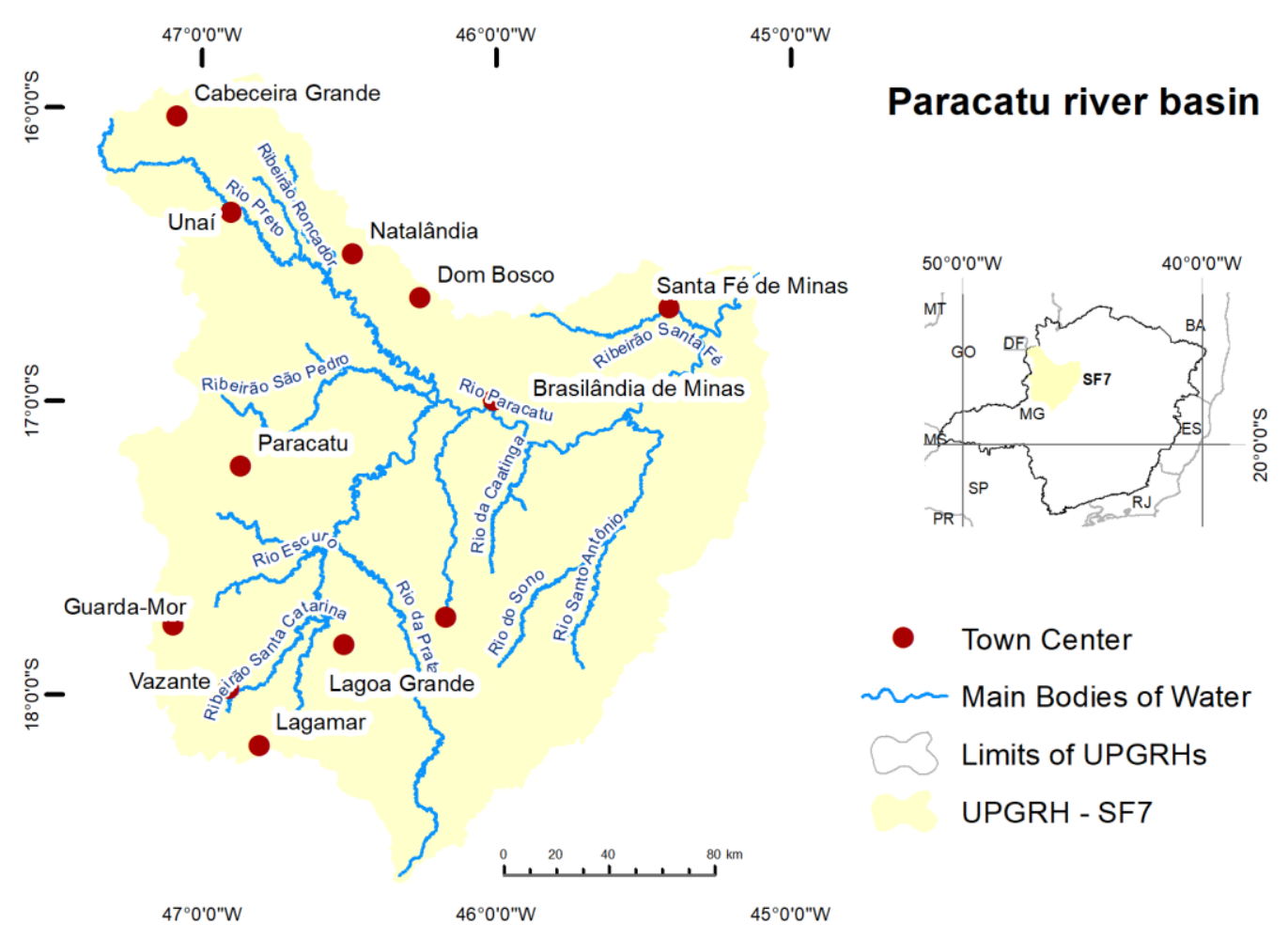

Source of Data: a) Hydrography (Igam, 2010), b) Water Resources Planning and Management Units (Igam, 2017) and, c) Municipal Headquarters (IEDE, 2017). Projection: Latitude/Longitude - Datum Sirgas 2000. 
Evaluation of potential use of domestic treated effluents for irrigation in areas subject to conflicts over water use in Paracatu river basin
Marília Carvalho de Melo

Ana Sílvia Pereira Santos Nádia Antônia Pinheiro Santos Bruna Magalhães de Araújo Josiane Rosa Silva de Oliveira Alessandro Ribeiro Campos

In the state of Minas Gerais, the basin belongs to the Water Resources Planning and Management of Water Resources - Paracatu River Basin (UPGRH SF7). It is situated in the Northwest Macroregion of the state and covers fully or partially the following municipalities: Bonfinópolis de Minas, Brasilândia de Minas, Buritizeiro, Cabeceira Grande, Dom Bosco, Guarda-Mor, João Pinheiro, Lagamar, Lagoa Grande, Natalândia, Paracatu, Patos de Minas, Presidente Olegário, Santa Fé de Minas, Unaí and Vazante.

The main economic activities found in the basin are livestock, mineral exploration and agriculture (REZENDE, 2013). The latter represents the main demand for water, corresponding to $86.6 \%$ of the total water usage. The basin has 1,238 pivots, distributed mainly into sub-basins of the Entre Ribeiro creek and the Preto river which represents $53 \%$ of the entire irrigated area in the basin (RODRIGUEZ et al., 2007; PRUSKI et al., 2007; EMBRAPA, 2014). The main crops in the study area are sugarcane, corn, soybeans and beans (IBGE, 2017).

According to Rodrigues et al. (2013) in the 1970s, at the start of the process of economic occupation and expansion of agricultural areas stimulated by the "Plano de Desenvolvimento Integrado no Noroeste Mineiro" (Regional Northwest Integrated Development Plan), we began to see the conflicts over water use. As economic development in the basin stepped up, the tendency was for increased water demand, bringing about higher pressure on water resources. Thus, because of the intense use of water, four areas of conflict over water use emerged in the last few years, regulated by a single process or collective grant, as shown in Table 1.

The collective grant or single granting process consist of an instrument of water allocation among the most diverse needs in a water basin, whose objective is to regulate the use of water by the users in the area of conflicts. This allocation (distribution) of water must target the following minimum goals: meet the environmental, economic and social needs for water; reduce or eliminate conflicts among water users and allow planning of future demands to be met.

Table 1 - Declared areas of conflict in the Paracatu river basin.

\begin{tabular}{lcc}
\hline \multicolumn{1}{c}{ DAC $^{\star}$} & Municipality & Watercourse \\
\hline $004 / 2006$ & Paracatu & Boa Esperança Stream \\
$002 / 2006$ & Paracatu and Unaí & Entre Ribeiros Creek \\
$001 / 2008$ & Paracatu & Engenho Velho Stream \\
$003 / 2015^{\text {a }}$ & João Pinheiro & Caatinga River \\
\hline
\end{tabular}

Source: IGAM (2006). Note: DAC - "Declaração de área de conflito" (Declared area of conflict); ' DAC not considered in this study, given that it is under the process of formalization, collective grant, with IGAM, the State Institute for Water Resources Management

\section{METHODOLOGICAL STAGES}

This study has been divided into three methodological stages, namely:

\section{Stage 1 - Quantification and comparison between the water demands for irrigation and generation of effluents from STPs in operation within the studied basin}

In order to quantify the water demands in the Paracatu river basin, we considered the surface grants issued in the conflict area (Table 1), available in the Integrated System of Environmental Data (Siam), of the State Institute of Water Management (Igam). It was taken into consideration the total amount of grants in each sub basin with formalized Declared Area of Conflict (DAC), that is, the Streams of Boa Esperança and Engenho Velho and Entre Ribeiros Creek, and for each one of them the following variables were defined:

- Irrigated area;

- Location (latitude and longitude);

- Outflow rate; and

- Irrigation technique.

Regarding the generation of effluents, we adopted the data provided in the "Atlas Esgotos - Despoluição de Bacias Hidrográficas" (Sewers Atlas - Clean-up of Water Basins) (ANA, 2017a).
Caminhos de Geografia
Uberlândia-MG
v. 21, n. 75
Jun/2020
p. 52-63
Página 55 
Evaluation of potential use of domestic treated effluents for irrigation in areas subject to conflicts over water use in Paracatu river basin
Marília Carvalho de Melo

Ana Sílvia Pereira Santos Nádia Antônia Pinheiro Santos Bruna Magalhães de Araújo Josiane Rosa Silva de Oliveira Alessandro Ribeiro Campos

In this case, for the generation of effluent for reuse were considered the STP's in operation in the basin with flowcharts corresponding minimally to a secondary stage. Of all assessed STPs, only the one located in the municipality of Natalândia (Minas Gerais) has only one an anaerobic reactor in its flowchart, with an average removal efficiency of organic matter limited to $65 \%$. Thus, this unit was not taken into account in this study, and the other STP's considered are shown in Table 2. Furthermore, these effluents would only be ready for reuse after the stage of disinfection. Thus, it is necessary to take into consideration the implementation of this step in the flowchart of the STP's listed in the study. Let it be noted that the Guarda-Mor STP, located in that municipality, has a maturation pond in its flowchart. It is known that under the appropriate conditions of operation this technology acts as disinfection stage.

Table 2 - Sewer Treatment Plants in the municipalities situated in the Paracatu river basin.

\begin{tabular}{lcccc}
\hline Municipality & STP & Efficiency (\%) & Outflow Rate (L/s) & Technology \\
\hline Paracatu & Paracatu & 77 & 75.4 & AnP+FP \\
Unaí & Unaí & 75 & 124 & AnP+FP \\
João Pinheiro & João Pinheiro & 81 & 38.8 & AnR+AF+SS \\
Vazante & Vazante & 90 & 21.5 & AnR+AnF \\
Guarda-Mor & Guarda-Mor & 74 & 4.7 & AnR+MP \\
\hline \multicolumn{1}{c}{ TOTAL } & & & 264.4 & \\
\hline
\end{tabular}

Source: Adaptation of ANA (2017). Legend: AnP - Anaerobic Pond; FP -Facultative Pond; AnR - Anaerobic Reactor; AF - Aerobic Filter; SS - Secondary Settler; AnF - Anaerobic Filter; MP - Maturation Pond.

Lastly, at this stage, the water demand for irrigation and the volume of effluent generated in these STPs in the study area have been compared.

\section{Stage 2 - Estimate of cost of transportation of reuse water by means of tank trucks}

For the progress of this stage, the methodology developed by Araújo et al. (2017) has been adapted. Initially, it was necessary to obtain the unit cost $\left(\mathrm{R} \$ / \mathrm{m}^{3}\right)$ of transport of water by tank trucks (Code 5747) from the National System of Research of Civil Construction Costs and Indexes (SINAPI). Thus, based on code 5747 the value has been extracted, in effect in May 2018, for the transportation carried out by means of tank trucks with $6 \mathrm{~m}^{3}$ capacity for the state of Minas Gerais.

In order to make possible the comparison with the value charged for the use of raw water, the cost of transportation of effluent for reuse (CTa) has been estimated using Equation 1.

$$
C T a_{(R \$ / m 3)}=\operatorname{CTunt} x\left(\frac{D}{v}\right)
$$

Equation 1

Where:

CTunt - represents the unit cost of transportation $\left(\mathrm{R} \$ / \mathrm{m}^{3} \mathrm{~min}\right)$.

$D$ - Accumulated distance traveled in highway $(\mathrm{m})$.

$v$-average speed, considering the recommended safe speed of $60 \mathrm{~km} / \mathrm{h}$.

The simulation of the distance traveled between each STP and all pivots was obtained using the Cost Distance algorithm available in spatial tools library of the software ArcGIS.

The matrix surfaces of accumulated distance traveled on highway to the STP under evaluation, considering the road network of Department of Buildings and Roads of Minas Gerais (DEER / MG), were combined to generate the map of the traveled distance. This was from cell-to-cell, to the nearest STP, considering distances range at intervals of every $10 \mathrm{~km}$ to the maximum of $100 \mathrm{~km}$.

\section{Stage 3 - Comparison between the charge for use of water resources and estimated cost of transportation of effluent for reuse.}

For the progress of this stage, it was necessary to initially estimate the charge for use of raw water for irrigation. Since the Paracatu river basin does not adopt its own methodology for charging for water, we adopted that foreseen in Deliberation No. 94 of the São Francisco river Committee, published on August

$\begin{array}{lllll}\text { Caminhos de Geografia } \quad \text { Uberlândia-MG } & \text { v. 21, n. } 75 & \text { Jun/2020 } & \text { p. } 52-63 & \text { Página } 56\end{array}$


Evaluation of potential use of domestic treated effluents for irrigation in areas subject to conflicts over water use in Paracatu river basin
Marília Carvalho de Melo Ana Sílvia Pereira Santos Nádia Antônia Pinheiro Santos Bruna Magalhães de Araújo Josiane Rosa Silva de Oliveira Alessandro Ribeiro Campos

26th, 2017 (BRAZIL, 2017) and approved by National Council of Water Resources, through Resolution No. 199 , dated June 28th, 2018 (CNRH). The water used for this type of consumption is normally obtained directly from bodies of water and there is no production of effluent. Thus, precisely for this type of irrigation, the cost of water consumption is calculated according to Equation 2, as show just below:

$$
V_{\text {cons }}=Q_{\text {cap }} \times K_{\text {c.irrig }} \times K_{\text {clas }} \times K_{\text {sist }} \times K_{\text {man }} \times P P U_{\text {cons }}
$$

Equation 2

Where:

$V_{\text {cons }}$ - Annual payment for water consumption (R $\$ /$ year).

$Q_{c a p}$ - Total annual volume of water collected ( $\mathrm{m}^{3} / \mathrm{year}$ ).

$K_{\text {c.irrig }}$ - Coefficient that quantifies the volume of water consumed in relation to the irrigation method used.

$K_{\text {clas }}$ - Coefficient that takes into account the class of framing of the body of water where the capture is made.

$K_{\text {sist }}$ - Coefficient that takes into account the efficiency of water use.

$K_{\text {man }}$ - Coefficient that takes into account the soil management and management of the water used in irrigation.

$P P U_{\text {cons }}-$ Public Unit Price for water consumption $\left(\mathrm{R} \$ / \mathrm{m}^{3}\right)$.

In line with the charge methodology presented in Deliberation No. 94 of 2017, the coefficients $\mathrm{K}_{\text {sist }}$ and $\mathrm{K}_{\text {cons }}$ take into account the type of technology employed which in the Paracatu river basin is mostly performed by central pivots. Thus, in Table 3, the coefficients adopted for the calculation for the cost of raw water use are shown.

Table 3 - Coefficients applied to the charges for the use of raw water for central pivot, in the São Francisco river basin.

\begin{tabular}{lccccccc}
\hline Irrigation Technology & $\mathbf{1}$ & $\mathbf{2}$ & $\mathbf{3}$ & $\mathbf{4}$ & $\mathbf{5}$ & $\mathbf{6}$ & $\mathbf{7}$ \\
\hline APC & 0,024 & 1 & 0,15 & 1 & 0,85 & 1 & 1 \\
APC L & 0,024 & 1 & 0,10 & 1 & 0,90 & 1 & 1 \\
\hline
\end{tabular}

Source: Adaptation of BRASIL (2017). Legend: APC - Central Pivot System Sprinkler; APC L - LEPA Central Pivot System Sprinkler.

Afterwards, a comparison was made between the estimated cost of transportation of effluent for reuse obtained in the second stage, with an approximate amount to charge for use of water resource for irrigation. This estimate does not take into consideration the cost of treatment, pumping and adduction of the treated effluent.

\section{RESULTS}

In a similar way to the methodology, the results will be presented in three stages, as follows:

\section{Stage 1 - Quantification and comparison between the water demands for irrigation and generation of effluents from STPs in operation within the studied basin}

Table 4 shows the summary of the main data regarding grants for irrigation demand for the areas related to the streams of Boa Esperança and Engenho Velho, and Entre Ribeiros Creek.

Table 4 - Grants awarded in the conflict areas in the Paracatu River Basin.

\begin{tabular}{cccccc}
\hline DAC & Geographical Coordinates & $\mathbf{N}^{\circ}$ Outg. & Irrigated Area (ha) & Outflow (L/s) & Annual Volume $\left(\mathbf{m}^{3}\right)^{\mathrm{a}}$ \\
\hline $004 / 2006$ & $17^{\circ} 13^{\prime} 17,9^{\prime \prime} \mathrm{S} 46^{\circ} 30^{\prime} 54,3^{\prime \prime} \mathrm{W}$ & 12 & $1,546.91$ & 1,076 & $6,235,718$ \\
$002 / 2006$ & $16^{\circ} 58^{\prime} 58,8^{\prime \prime} \mathrm{S} 46^{\circ} 14^{\prime} 16,8^{\prime \prime} \mathrm{W}$ & 114 & $16,620.32$ & 13,820 & $150,081,088$ \\
$001 / 2008$ & $17^{\circ} 05^{\prime} 16^{\prime \prime} \mathrm{S} 46^{\circ} 39^{\prime} 35^{\prime \prime} \mathrm{W}$ & 7 & $5,369.4$ & 2,760 & $25,360,733$ \\
\hline TOTAL & & 133 & $23,526.63$ & 17,656 & $181,677,539$ \\
\hline
\end{tabular}

Source: IGAM (2006). Note: DAC - "Declaração de área de conflito" (Declared area of conflict); № Outg. - Water Resources Use Rights Grant; ${ }^{a}$ The volume was calculated taking into account the irrigation frequency in the process of granting. 
Evaluation of potential use of domestic treated effluents for irrigation in areas subject to conflicts over water use in Paracatu river basin
Marília Carvalho de Melo

Ana Sílvia Pereira Santos Nádia Antônia Pinheiro Santos

Bruna Magalhães de Araújo Josiane Rosa Silva de Oliveira Alessandro Ribeiro Campos

The areas of conflict and their respective uses for irrigation in the Paracatu river basin are shown in Figure 2.

Figure 2 - Declared areas of conflict in the Paracatu river basin (Minas Gerais).

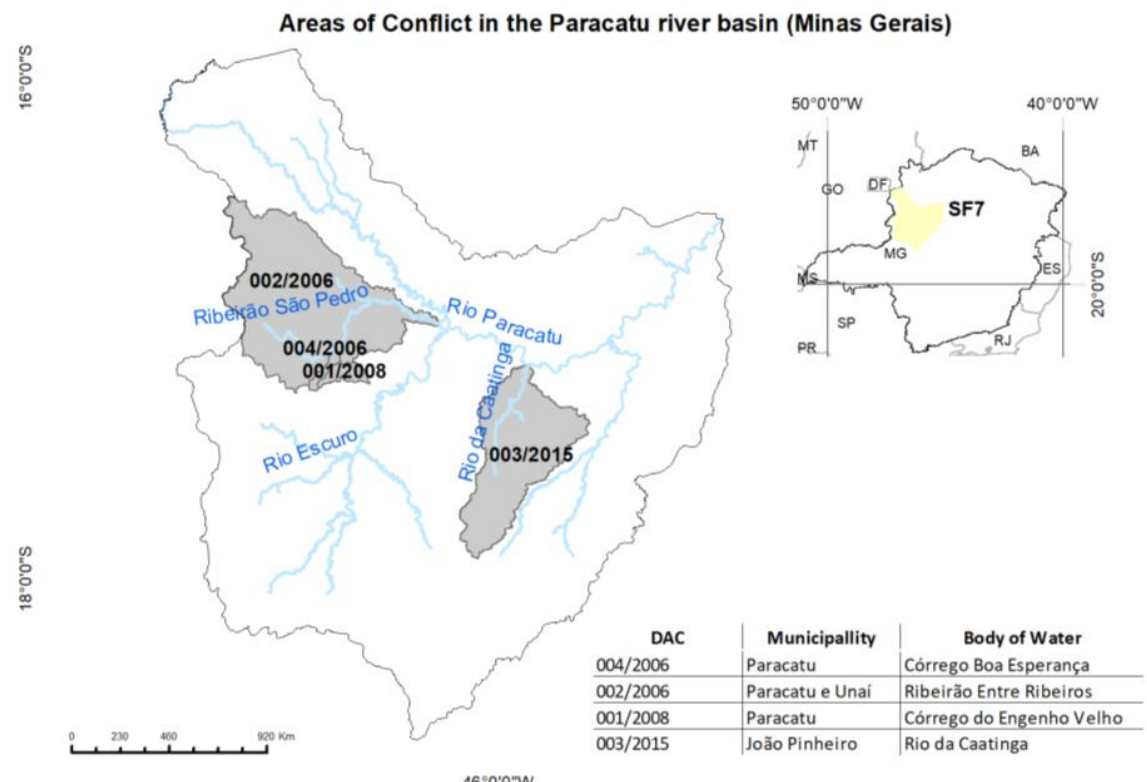

Source of Data: a) Hydrography (Igam, 2010), b) Units of Planning and Management of Water Resources (Igam, 2017) and c) Declaration of Conflict Areas (Igam, 2019). Projection: Latitude/Longitude -

Datum Sirgas 2000.

Regarding the generation of effluent for reuse from the STP effluents, Table 5 shows the annual volume of sewage produced at each STP studied herein considering the average outflow of the STP produced in the 24 hours of the day, 365 days a year, according to data obtained from the Atlas Água e Esgoto (ANA, 2017a) (Atlas Water and Sewerage).

Table 5 - Annual volume of sewage produced in Sewage Treatment Plants of municipalities based in the Paracatu river basin.

\begin{tabular}{lcccc}
\hline Municipality & STP & Outflow Rate (L/s) & Annual Volume & $\left.\mathbf{( m}^{\mathbf{3}}\right)$ \\
\hline Paracatu & Paracatu & 75.4 & $2,377,814$ \\
Unaí & Unaí & 124 & $3,910,464$ \\
João Pinheiro & João Pinheiro & 38.8 & $1,223,597$ \\
Vazante & Vazante & 21.5 & 678,024 \\
Guarda-Mor & Guarda-Mor & 4.7 & 148,219 \\
\hline \multicolumn{1}{c}{ TOTAL } & & 264.4 & $8,338,118$ \\
\hline
\end{tabular}

Source - Adaptation of ANA (2017).

Thus, Table 6 shows the comparison between the water demand for irrigation, summarized in Table 4, and the supply of water for reuse offered by the selected STPs in the Paracatu river basin, shown in Table 5.

Table 6 - Comparison between annual volume of irrigation demand and volume produced by the STPS.

\begin{tabular}{cc}
\hline \multicolumn{2}{c}{ Annual Volume $\left(\mathbf{m}^{3}\right)$} \\
\hline Demand for irrigation & Water for reuse offered by STPs \\
\hline $181,677,539$ & $8,338,118$ \\
\hline
\end{tabular}

Source: by author.

$\begin{array}{lllll}\text { Caminhos de Geografia } \quad \text { Uberlândia-MG } & \text { v. 21, n. } 75 & \text { Jun/2020 } & \text { p. } 52-63 & \text { Página } 58\end{array}$


Evaluation of potential use of domestic treated effluents for irrigation in areas subject to conflicts over water use in Paracatu river basin
Marília Carvalho de Melo Ana Sílvia Pereira Santos Nádia Antônia Pinheiro Santos Bruna Magalhães de Araújo Josiane Rosa Silva de Oliveira Alessandro Ribeiro Campos

It can be observed that, in terms of instantaneous outflow, those users who already possess grants, there is a demand for approximately 17,656 L/s (Table 4), not considering the increased demand. In relation to the outflow presented by the STPs, the total volume produced parallels only $265 \mathrm{~L} / \mathrm{s}$ (Table 5), corresponding to $1.5 \%$ of the volume of water required for irrigation.

Regarding the annual volume, for users who already possess grants, there is a demand of approximately $181,677,539 \mathrm{~m}^{3}$ per year, which corresponds to $4.60 \%$ of the water required for irrigation.

\section{Stage 2 - Estimated cost of effluent for reuse transport by water truck}

According to SINAPI (National System of Research of Civil Construction Costs and Indexes) May 2018, the cost of water transportation in the state of Minas Gerais by means of tank trucks is an average of $R \$ 92.89$ per hour for every $6 \mathrm{~m}^{3}$, or $R \$ 15.48$ per $\mathrm{m}^{3}$ per hour, which corresponds to $0.258 \mathrm{R} \$ / \mathrm{m}^{3} / \mathrm{min}$.

Therefore, the distances between the selected STPs and the irrigated areas were calculated, considering the access roads shown in Figures 3 and 4. Figure 3 shows specific maps for each STP whereas Figure 4 shows only one map with all data consolidated.

Figure 3 - Graphical representation of the distances between the STPs and the irrigation pivots of the irrigated areas located in the Paracatu river basin, in Minas Gerais, where each map represents a single STP.

\section{Distance range between Sewage Treatment Plants and irrigated areas located in the Paracatu river basin (Minas Gerais)}
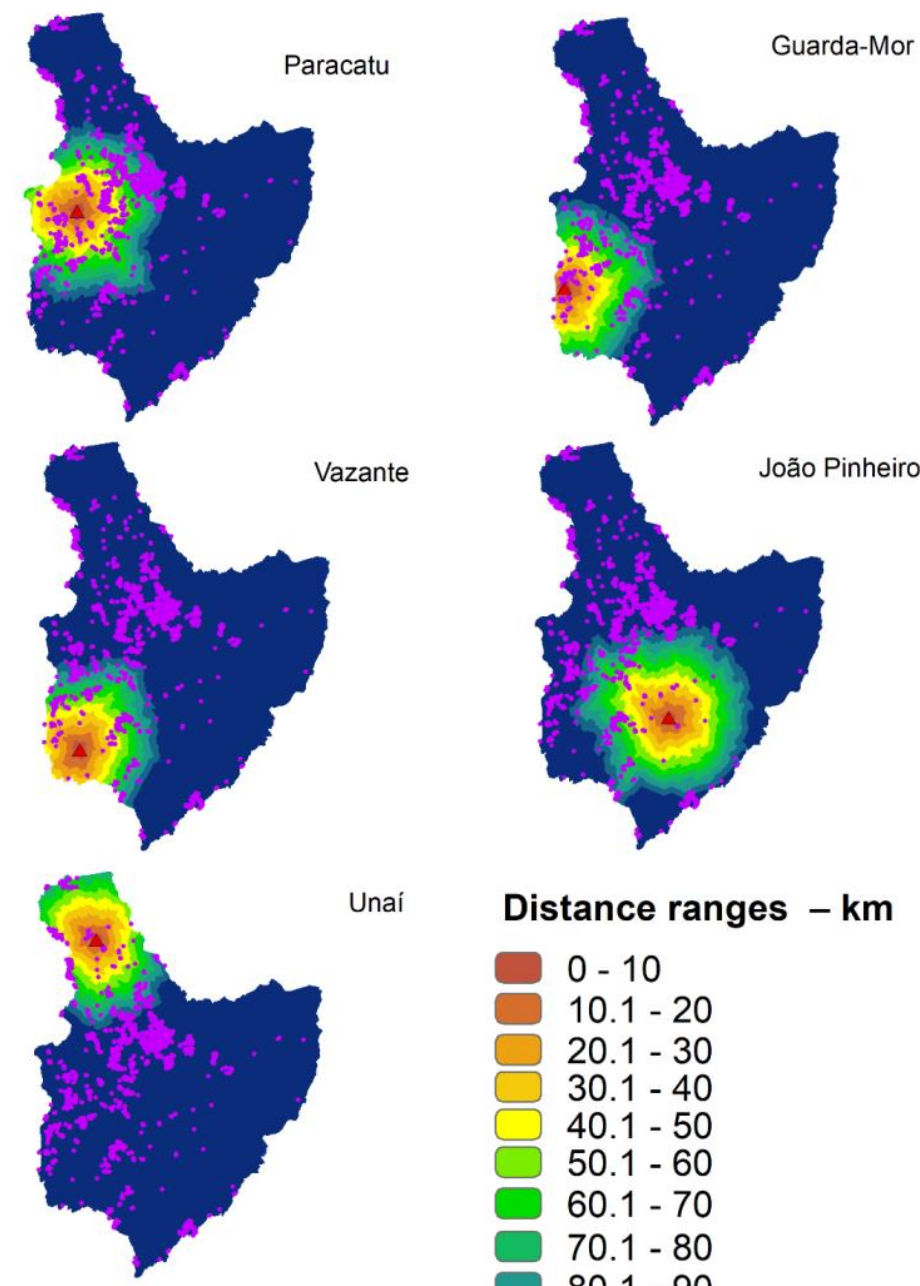

Unaí

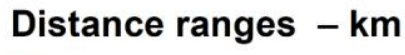

Agricultural Areas - Center Pivot

- Sewage Treatment Plants

- Road system

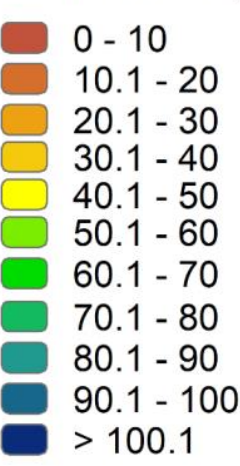

Source: a) Units of Planning and Management of Water Resources, Igam (2017) b) Irrigated Areas, Embrapa (2013) and c) Sewage Treatment Plant, ANA, 2018. Projection: Latitude/Longitude - Datum Sirgas 2000. 
Evaluation of potential use of domestic treated effluents for irrigation in areas subject to conflicts over water use in Paracatu river basin
Marília Carvalho de Melo

Ana Sílvia Pereira Santos Nádia Antônia Pinheiro Santos

Bruna Magalhães de Araújo Josiane Rosa Silva de Oliveira Alessandro Ribeiro Campos

Figure 4 - Graphical representation of distances between the STP's and irrigation pivots of the irrigated areas located in the Paracatu river basin, in Minas Gerais.

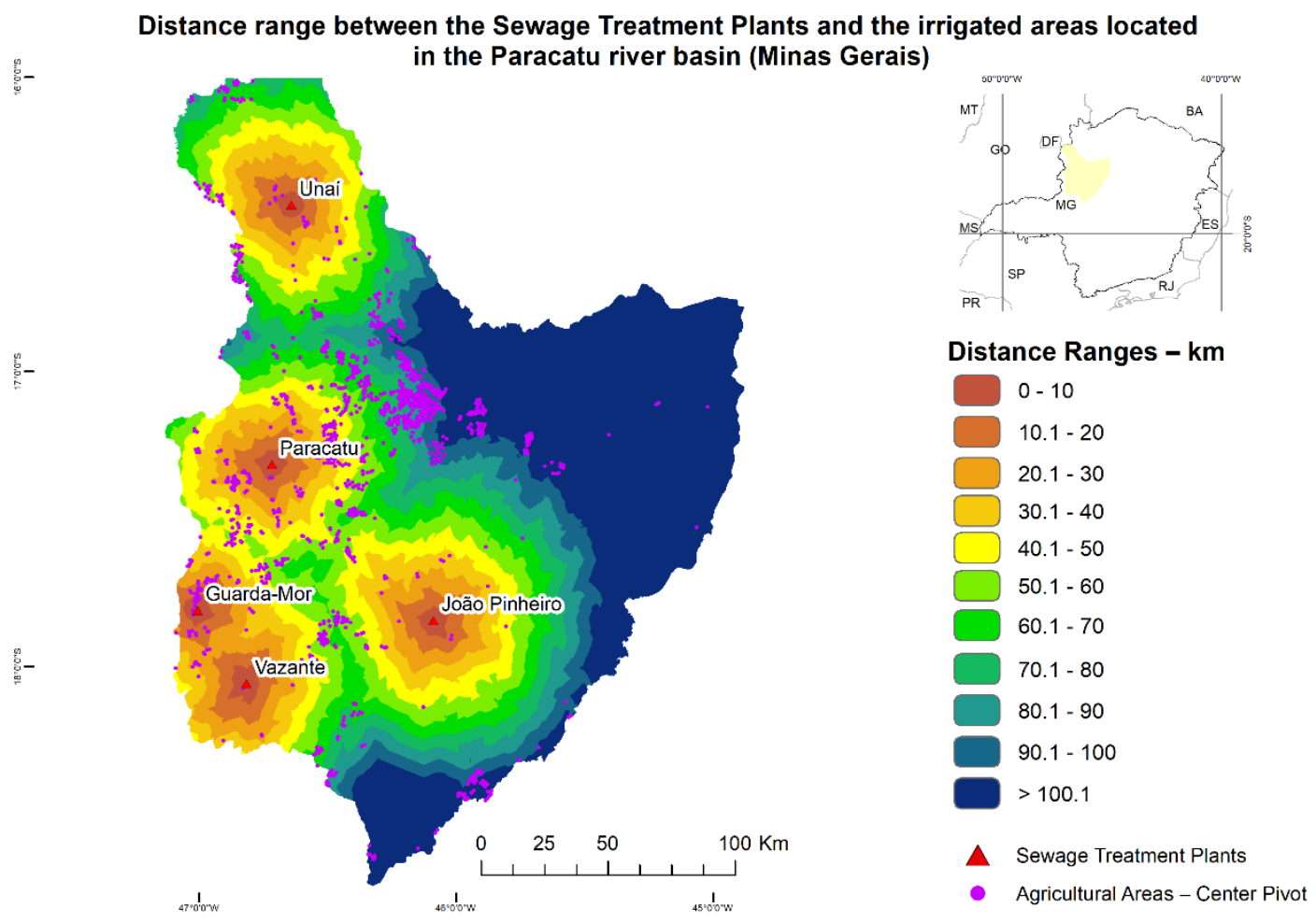

Source: a) Units of Planning and Management of Water Resources, Igam (2017) b) Irrigated Areas, Embrapa (2013) and c) Sewage Treatment Plant, ANA, 2018. Projection: Latitude/Longitude - Datum Sirgas 2000.

Table 7 shows the number of pivots served in each distance range and estimated costs for transportation of effluent for reuse, according to methodology developed by Araújo et al. (2017), utilizing amounts defined by SINAPI (2018).

Table 7 - Coefficients applied to the charges for the use of raw water for central pivot, in the São Francisco river basin.

\begin{tabular}{cccccc}
\hline Distance & $\mathbf{V}(\mathbf{k m} / \mathbf{h})$ & $\mathbf{\Delta} \mathbf{D}(\mathbf{k m})$ & $\mathbf{\Delta} \mathbf{T}(\mathbf{m i n})$ & $\mathbf{C T}\left(\mathbf{R} \mathbf{\$} \mathbf{m}^{3}\right)$ & $\mathbf{N}^{\circ}$ Pivot \\
\hline $0-10$ & 60 & 10 & 10 & 2.58 & 45 \\
$10.1-20$ & 60 & 20 & 20 & 5.16 & 48 \\
$20.1-30$ & 60 & 30 & 30 & 7.74 & 89 \\
$30.1-40$ & 60 & 40 & 40 & 10.32 & 99 \\
$40.1-50$ & 60 & 50 & 50 & 12.90 & 131 \\
$50.1-60$ & 60 & 60 & 60 & 15.48 & 165 \\
$60.1-70$ & 60 & 70 & 70 & 18.06 & 120 \\
$70.1-80$ & 60 & 80 & 80 & 20.64 & 120 \\
$80.1-90$ & 60 & 90 & 90 & 23.22 & 187 \\
$90.1-100$ & 60 & 100 & 100 & 25.80 & 121 \\
$>100$ & 60 & $>100$ & $>100$ & variable & 113 \\
\hline TOTAL & & & & & 1,238
\end{tabular}

Notes: V- Average Speed; $\Delta \mathrm{D}$ - Distance Traveled; $\Delta \mathrm{T}$ - Time required to reach destination; $\mathrm{CT}$ - Cost of Transportation; No. Pivot - number of pivots served in each distance range. 
Evaluation of potential use of domestic treated effluents for irrigation in areas subject to conflicts over water use in Paracatu river basin
Marília Carvalho de Melo

Ana Sílvia Pereira Santos Nádia Antônia Pinheiro Santos Bruna Magalhães de Araújo Josiane Rosa Silva de Oliveira Alessandro Ribeiro Campos

Whereas the demand for irrigation is $181,677,539 \mathrm{~m}^{3}$ per year for 1238 pivots, there is an average demand for $146,750.84 \mathrm{~m}^{3}$ per pivot. In regard to the volume produced by the STPs for reuse, there is a total of $8,356,982 \mathrm{~m}^{3}$ per year, which meets an average demand of 57 pivots. Therefore, as shown on Table 6, all pivots within the $10 \mathrm{~km}$ range and 12 pivots in the subsequent range would be met.

\section{Stage 3 - Comparison between costs of water resources usage and the estimated cost of transportation of effluent for reuse}

Next, the amount charged for usage of water resources was compared to the cost of transportation of reuse water by tank trucks, which were obtained in Stage 2. These amounts are in Brazilian currency (BRL) per m3, as shown in Table 8.

Table 8 - Comparison between the SINAPI cost and the amount charged for usage of raw water, considering the distances traveled (charges for water usage / SINAPI) in \%.

\begin{tabular}{lccccc}
\hline \multirow{2}{*}{$\begin{array}{c}\text { Irrigation } \\
\text { Technology }\end{array}$} & \multicolumn{5}{c}{ Ratio between amount charged for usage of raw water and } \\
\cline { 2 - 6 } & $\mathbf{1 0 ~} \mathbf{~ k m}$ & $\mathbf{2 0 ~} \mathbf{~ k m}$ & $\mathbf{3 0 ~} \mathbf{~ m}$ & $\mathbf{4 0 ~} \mathbf{~ k m}$ & $\mathbf{5 0 ~} \mathbf{~ k m}$ \\
\hline APC & 0.12 & 0.06 & 0.04 & 0.03 & 0.02 \\
APC L & 0.08 & 0.04 & 0.03 & 0.02 & 0.02 \\
\hline
\end{tabular}

Legend: APC - Central Pivot System Sprinkler; APC L - LEPA Central Pivot System Sprinkler.

The numbers shown in Table 8 lead to the conclusion that there is no economic advantage in using reuse water considering the low rates charged for raw water.

\section{CONCLUSIONS}

The prices applicable in Minas Gerais do not stimulate recognition of water as an economic asset and do not even provide the users with an indication of its real value. Consequently, this does not encourage the rationalization of water use and makes it economically difficult to include the practice of reuse in the areas addressed in this study. This is due to the costs of transportation of effluent for reuse, though reduced, as they are not competitive economically if compared to the low value charged for the use of water for irrigation, calculated as of the Deliberation No. 94 / 2017.

On the other hand, considering it involves areas of conflict, those regions whose demand exceeds water availability, water becomes a scarce resource and shortage may limit the expansion of economic activities, mainly those directly dependent on this resource, namely the agriculture. Thus, although the prices charged are lower than those of reuse water, it is essential to consider reuse as a solution for maintenance of the activities.

It is important to evaluate the possibility of further reduction in the costs of production of each crop by adopting water reuse as a source of water and also fertilizer (a process known as fertigation).

To conclude, considering that in the Paracatu river basin the effluents of the STPs can only comply with $4.60 \%$ of the demand for irrigation, it is strategic to contemplate in future studies different alternative sources of water, besides domestic reuse, such as reuse of rainwater and management of the demand to promote techniques and technologies for the efficient use of water in irrigation and in other important uses of water in the basin, such as those from the industries and mining activities.

\section{ACKNOWLEDGEMENT}

The authors woud like to thank IGAM, the State Institute for Water Resources Management

$\begin{array}{lllll}\text { Caminhos de Geografia } \quad \text { Uberlândia-MG } & \text { v. 21, n. } 75 & \text { Jun/2020 } & \text { p. 52-63 } & \text { Página } 61\end{array}$


Evaluation of potential use of domestic treated effluents for irrigation in areas subject to conflicts over water use in Paracatu river basin
Marília Carvalho de Melo

Ana Sílvia Pereira Santos Nádia Antônia Pinheiro Santos Bruna Magalhães de Araújo Josiane Rosa Silva de Oliveira Alessandro Ribeiro Campos

\section{REFERENCES}

ANA - AGÊNCIA NACIONAL DE ÁGUAS. Atlas esgotos: despoluição de bacias hidrográficas, 88p. Brasília, 2017a. Disponível em: http://atlasesgotos.ana.gov.br/. Acesso em: nov. 2018

ANA - AGÊNCIA NACIONAL DE ÁGUAS. Atlas Irrigação: Uso da água na agricultura irrigada, 86p. Brasília, 2017b. Disponível em: http://arquivos.ana.gov.br/imprensa/publicacoes/AtlaslrrigacaoUsodaAguanaAgriculturalrrigada.pdf. Acesso em: nov. 2018.

ANA - AGENCIA NACIONAL DAS ÁGUAS. Análise custo-benefício de medidas de adaptação à mudança do clima: trajetórias da aplicação na bacia hidrográfica dos rios Piancó-Piranhas-Açu. 2018. .Disponível em: http://mediadrawer.gvces.com.br/publicacoes-2/original/fgvces-acb-pianco-piranhasacu.pdf. Acesso em: nov. 2018

ANGELAKIS A. N.; MARECOS DO MONTE, M. H. F.; BONTOUX L; ASANO T. The status of wastewater reuse practice in the mediterranean basin: need for guidelines. Water Research, v. 33, n. 10, p. 2201-2217, july, 1999. https://doi.org/10.1016/S0043-1354(98)00465-5

ARAUJO, B. M.; SANTOS, A. S. P.; SOUZA, F. P. Comparativo econômico entre o custo estimado do reuso do efluente de ETE para fins industriais não potáveis e o valor da água potável para a região sudeste do Brasil. Perspectivas Online Ciências Exatas e Engenharia, v. 17, n. 7, p. 51-61, Campos dos Goytacazes, 2017.

ARAUJO, B. M.; SANTOS, A. S. P.; SOARES, S. R. A.; MELO, M. C.; OHNUMA JR., A. A. Aspectos econômicos para o reuso na agricultura na bacia do rio Paraíba do Sul e comparação com o modelo da gestão de cobrança de Israel. In: III Simpósio de Recursos Hídricos do Rio Paraíba do Sul, 2018, Juiz de Fora, MG, 2018a.

ARAUJO, B. M.; SILVA JR., L. C. S.; SANTOS, A. S. P.; BILA, D. M. Comparativo econômico entre o custo estimado do reuso do efluente de ETE para fins não potáveis e o valor da água potável para a bacia do rio Paraíba do Sul. In: III Simpósio de Recursos Hídricos do Rio Paraíba do Sul, 2018, Juiz de Fora, MG, 2018b.

BRASIL. Deliberação Comitê de Bacia Hidrográfica do Rio São Francisco (CBHRS) $n^{\circ} 94$ de 25 de agosto de 2017. Atualiza, estabelece e sugere novos valores de cobrança pelo uso de recursos hídricos na bacia hidrográfica do rio São Francisco. Brasília, 25 de agosto de 2017. Disponível em: http://cbhsaofrancisco.org.br/2017/?wpfb dl=2337. Acesso em: 8 mar. 2019.

CASTRO, J. E. Water Governance in the twentieth-first century. Ambiente e Sociedade, v. 10, n. 2, p. 97118, Campinas, july/dec, 2007. https://doi.org/10.1590/S1414-753X2007000200007

CAVALCANTI, B. S.; MARQUES, G. R. G. Recursos hídricos e gestão de conflitos: A bacia hidrográfica do rio Paraíba do Sul a partir da crise hídrica de 2014-2015. RGPLP: Revista de Gestão dos Países de Língua Portuguesa, v. 15, n. 1, p. 6-16, Lisboa, mar. 2016. https://doi.org/10.12660/rgplp.v15n1.2016.78411

CONSELHO NACIONAL DE RECURSOS HÍDRICOS (CNRH). Resolução n` 199 de 28 de junho de 2018. Aprova os mecanismos e valores de cobrança pelo uso de recursos hídricos de domínio da união na bacia hidrográfica do rio São Francisco. Brasília, 2018. Disponível em: http://www.in.gov.br/materia/lasset publisher/Kuirw0TZC2Mb/content/id/45574659. Acesso em: 8 mar. 2019.

EMBRAPA - EMPRESA BRASILEIRA DE PESQUISA AGROPECUÁRIA. Pivôs Centrais de Irrigação. Sete Lagoas, 2014. Disponível em: http://metadados.ana.gov.br/geonetwork/srv/pt/main.home. Acesso em: 17 jul. 2018.

ER, M. L.; CUNHA, T. R.; ROSANELI, C. F.; MOLINARI, R. B.; SGANZERLA A. Crise hídrica em publicações científicas: olhares da bioética ambiental. Revista Ambiente \& Água, v. 11, n. 3, p. 587-600, july/sept. 2016. https://doi.org/10.4136/ambi-agua.1879

HESPANHOL, I. Potencial de reuso de água no Brasil - Agricultura, indústria, municípios e recarga de aquíferos. Revista Brasileira de Recursos Hídricos, v.7, p.75-95, 2002. https://doi.org/10.21168/rbrh.v7n4.p75-95

IBGE - INSTITUTO BRASILEIRO DE GEOGRAFIA E ESTATÍSTICA. Censo Agropecuário (Resultados preliminares) 2017. Disponível em: https://sidra.ibge.gov.br/pesquisa/censo-agropecuario/censoagropecuario-2017. Acesso em 30 jul. 2018.

$\begin{array}{lllll}\text { Caminhos de Geografia } & \text { Uberlândia-MG } & \text { v. } 21, n .75 & \text { Jun/2020 } & \text { p. } 52-63\end{array}$


Evaluation of potential use of domestic treated effluents for irrigation in areas subject to conflicts over water use in Paracatu river basin
Marília Carvalho de Melo Ana Sílvia Pereira Santos Nádia Antônia Pinheiro Santos Bruna Magalhães de Araújo Josiane Rosa Silva de Oliveira Alessandro Ribeiro Campos

IGAM - INSTITUTO MINEIRO DE GESTÃO DAS ÁGUAS IGA. Plano Diretor de Recursos Hídricos da Bacia Hidrográfica do Rio Paracatu. Belo Horizonte, MG, 2006. Disponível em: http://portalinfohidro.igam.mg.gov.br/gestao-das-aguas/planos. Acesso em: 06 jun. 2018.

JUANICÓ, M. Reutilización de águas residuales. Qué se puede aprender de la experiencia israelí.. Revista Tecnologia del agua, v.27, n. 285, p.58-69, 2007.

LUBELLO, C.; GORI, R.; INCISE, F. P.; FERRINI, F. Municipal-treated wastewater reuse for plant nurseries irrigation. Water Research, v.38, n. 12, p.2939-2947, july 2004. https://doi.org/10.1016/i.watres.2004.03.037

MARIN, P.; TAL, S.; YERES, J.; KLAS, R. Water Management in Israel. World Bank, 2017. Disponível em: https://openknowledge.worldbank.org/bitstream/handle/10986/28097/119309-WP-PUBLIC-56p-

WcmpeProof.pdf?sequence=1\&isAllowed=y. Acesso em 27 de jun. 2018

NICHELE, J. Utilização de efluentes sanitários tratados para o suprimento de nutrientes à cultura do milho e modificações em propriedades químicas do solo, Rio Grande do Sul, 2009. 75f. Dissertação (Mestrado) Programa de Pós-graduação em Ciência do Solo, Faculdade de Agronomia, Universidade Federal do Rio Grande do Sul, Porto Alegre.

ORON, G.; GOEMANS, M.; MANOR, Y.; FEYEN, J. Poliovirus distribution in the soil-plant system under reuse of secondary wastewater. Water Research, v. 29, n. 4, p. 1069-1078, april, 1995. https://doi.org/10.1016/0043-1354(94)00257-8

PRUSKI, F. F.; RODRIGUEZ, R. G.; NOVAES, L. F.; SILVA, D. D.; RAMOS, M. M; TEIXEIRA, A. F. Impacto das vazões demandadas pela irrigação e pelos abastecimentos e humano, na Bacia do Paracatu. Revista Brasileira de Engenharia Agrícola e Ambiental, v. 11, n. 2, p. 199-210, Campina Grande/PB, 2007. https://doi.org/10.1590/S1415-43662007000200011

REZENDE, P. S. Estudo ambiental no município de Paracatu, MG: quantificação, especiação e transporte de elementos tóxicos. 2013. 139f. Tese (Doutorado em Ciências - Química) - Instituto de Ciências Exatas Departamento de Química, Universidade Federal de Minas Gerais, Belo Horizonte, Minas Gerais, 2013.

RODRIGUEZ, R. G.; PRUSKI, F. F.; NOVAES, L. F.; RAMOS, M. M.; SILVA, D. D.; TEIXEIRA, A. F. Estimativa da demanda de água nas áreas irrigadas da bacia do rio Paracatu. Engenharia Agrícola, v. 27, n. 1, p.172-179, Jaboticabal, 2007. https://doi.org/10.1590/S0100-69162007000100011

SANTOS, A. S. P.; LIMA, M. A. M.; RAMOS, L. T. A; PEREIRA, C. B.; SOARES, S. R. A.; MELO, M. C. Estimativa da capacidade disponível de reuso de efluentes na bacia hidrográfica do Paraíba do Sul. In: III Simpósio de Recursos Hídricos do Rio Paraíba do Sul, 2018, Juiz de Fora, MG, 2018.

SANTOS, B. B. M. Segurança hídrica da região metropolitana do Rio de Janeiro: contribuições para o debate. Ambiente \& Sociedade, v. XIX, n. 1, p. 103-120, São Paulo, jan/mar 2016.

SIEGEL, S.M. Faça-se a água: a solução de Israel para um mundo com sede de água (Let there be water: Israel's solution for water-starverd world). São Paulo, EDUC, 350 p. 2017.

SILVA, K. C.; SANTOS, R. A.; SANTOS, A. S. P. Estudo sobre a atual situação do reuso de águas servidas tratadas no Brasil e no mundo. In: XVII Simpósio Luso Brasileiro de Engenharia Sanitária e Ambiental, 2016, Florianópolis, SC, 2016.

SOUZA, C. M. N. Gestão da água e saneamento básico: reflexões sobre a participação social. Saúde e Sociedade, v. 26, n. 4, São Paulo, oct/dec, 2017. https://doi.org/10.1590/s0104-12902017170556

TUNDISI, J. G. Recursos hídricos no futuro: problemas e soluções. Estudos Avançados, v. 22, n. 63, p. 716, São Paulo, 2008. https://doi.org/10.1590/S0103-40142008000200002

Recebido em: 08/09/2019

Aceito para publicação em: 03/03/2020 